
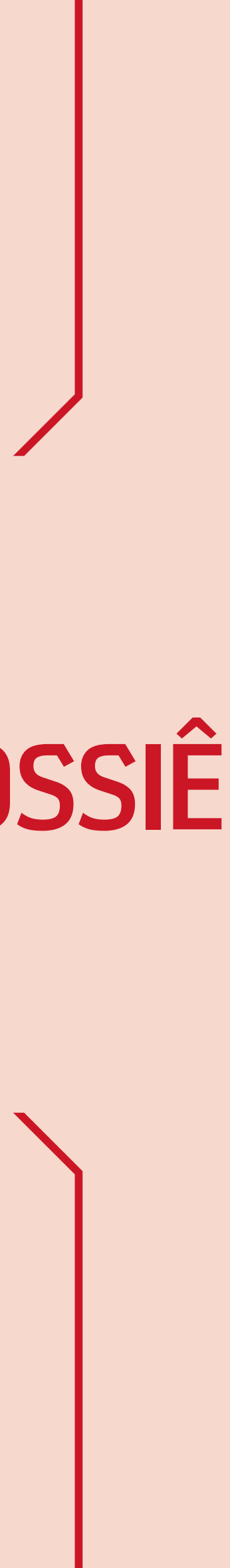


\section{O INSÓLITO NA NARRATIVA-MOLDURA DE A LENDA DA MEIA-NOITE, DE PINHEIRO CHAGAS}

\section{JEAN CARLOS CARNIEL*}

Universidade Estadual Paulista (Unesp), Programa de Pós-Graduação em Letras (PPGL), São José do Rio Preto, SP, Brasil.

Recebido em: 15 jan. 2021. Aprovado em: 4 mar. 2021.

Como citar este artigo: CARNIEL, J. C. 0 insólito na narrativa-moldura de $A$ lenda da meia-noite, de Pinheiro Chagas. Cadernos de Pós-Graduação em Letras, v. 21, n. 1, p. 20-37, jan./abr. 2021. doi: 10.5935/ cadernosletras.v21n1p20-37

\section{Resumo}

Objetivamos evidenciar a contribuição de Manuel Pinheiro Chagas para a literatura do insólito portuguesa, por meio da análise da narrativa-moldura da coletânea A lenda da meia-noite (1874), que reúne cinco contos insólitos.

\section{Palavras-chave}

Insólito. Narrativa-moldura. A lenda da meia-noite.

* E-mail: jc.carniel@hotmail.com

(D) https://orcid.org/0000-0002-3082-2983

Bolsista do CNPq. 


\section{INTRODUÇÃO}

Embora o nome de Manuel Joaquim Pinheiro Chagas (1842-1895) seja, atualmente, pouco conhecido pelo público leitor, esse português que, além de escritor, atuou também como historiador, jornalista e político foi bastante popular na segunda metade do século XIX, em sua terra natal. Jane Adriane Gandra Veloso (2007, p. 147), em estudo sobre a trajetória historiográfica de Pinheiro Chagas, verifica que o autor recebeu impressões negativas advindas das relações que ele mantivera com os intelectuais de sua época, ressaltando que "a exclusão de Chagas do cânone português deve-se em boa parte às polêmicas que disputou com Eça de Queirós”. As críticas mordazes feitas por Eça de Queirós teriam contribuído para o esquecimento e para o ostracismo de Pinheiro Chagas.

Por sua vez, objetiva-se divulgar uma obra literária pouco trabalhada pela academia, ressaltando a contribuição de Pinheiro Chagas para a literatura do insólito portuguesa. Apesar de ser lembrado como um autor de romances históricos, ele também escreveu contos fantásticos que foram reunidos em A lenda da meia-noite (1874). Nessa obra, são compiladas cinco narrativas curtas, a saber, "Julieta”, “A visão do precipício”, “A igreja profanada”, "Memórias de uma bolsa verde" e "Dominus tecum", que têm o insólito como elemento comum.

Parte desses textos já tinha sido publicada anteriormente em periódicos, e outros foram reunidos em antologias e em volumes de coleções sobre o fantástico português, ao longo do século XX. ${ }^{1}$ Entretanto, existe uma diferença significativa em relação à estrutura textual das narrativas quando publicadas conjuntamente em livro e quando compiladas separadamente, pois, em A lenda da meia-noite, os cinco contos constituem uma moldura, que forma uma narrativa maior. Contudo, não há essa marca quando publicados à parte. Portanto, objetiva-se compreender qual seria a importância da narrativa-moldura em A lenda da meia-noite e como ela se articula com o fantástico ou, mais propriamente, com o insólito.

1 Por exemplo, "A igreja profanada” foi lançada na Revista Contemporânea Portugal e Brasil (1863-1864). Essa mesma narrativa, posteriormente, é reunida na Antologia do conto fantástico português (1967 [1 $1^{a}$ edição]; 1974 [ $2^{a}$ edição]). "Memórias de uma bolsa verde" foi publicada no Arquivo Pitoresco, em 1864. Por seu turno, o conto "Julieta" é publicado separadamente num volume da Coleção Fantástico, n 16, da Edições Rolim, em 1985. 


\section{A NARRATIVA-MOLDURA ENTRE O INSÓLITO E A METAFICÇÃO}

Maria Cristina Batalha (2011, p. 12-13) destaca que, por volta de 1830, o termo "fantástico" estava "definitivamente associado ao nome do contista alemão E. T. A. Hoffmann, embora não tenha sido ele o criador do gênero”. O fantástico, para os românticos franceses, estaria relacionado ao modelo literário produzido por Hoffmann, como uma tentativa de desvinculação do gótico (cf. BATALHA, 2011, p. 12-13). O italiano Italo Calvino (2004, p. 10) também estabelece um parentesco entre as duas literaturas, afirmando que o gótico serviria de base para a consolidação do fantástico, pois ambos partilham temas comuns:

[...] é com o romantismo alemão que o conto fantástico nasce, no início do século XIX; mas já na segunda metade do século XVIII o romance "gótico" inglês havia explorado um repertório de temas, ambientes e efeitos (sobretudo macabros, cruéis, apavorantes).

Em A lenda da meia-noite, o gótico e o fantástico são tratados como equivalentes, o que reforça a afinidade entre eles. Pinheiro Chagas mostra um vasto conhecimento das narrativas insólitas europeias, por citar autores expoentes do fantástico, do gótico e do terror, como o alemão E. T. A. Hoffmann, os franceses Charles Nodier e Alexandre Dumas, e os ingleses Ann Radcliffe, Matthew Gregory Lewis e Charles Dickens. Todavia, quando mencionadas, as produções desses escritores aparecem sob a nomenclatura do fantástico ou do legendário, ${ }^{2}$ termos empregados pelos próprios personagens.

Batalha (2012, p. 497) considera que “a categoria do 'insólito' - traço comum a todo um conjunto de textos - seja adequado como modo de operacionalizar a reflexão sobre a literatura fantástica”. Com esse posicionamento, Batalha - e outros estudiosos que propõem o insólito como balizador da narrativa fantástica - reconhece a flutuação teórica que há no termo "fantástico" e em suas abordagens (como a abordagem genológica, defendida por estudiosos como Tzvetan Todorov, e a modal, seguida por Remo Ceserani).

Todorov é um dos pioneiros a pensar a literatura fantástica como um gênero literário. De acordo com a teoria todoroviana, o fantástico “dura ape-

2 De acordo com Lúcia Pimentel Goés (2009), a lenda, do latim legenda, "designava histórias de santos, mas o sentido estendeu-se para significar uma história ou tradição oriunda de tempos imemoriais e popularmente aceite como verdade". 
nas o tempo de uma hesitação" (TODOROV, 2014, p. 47). Segundo o autor, a hesitação, por um lado, deve provocar a incerteza entre a explicação natural e a explicação sobrenatural. Por outro, ela deve ser presenciada por um personagem, e é desejável que o leitor se identifique com as experiências vivenciadas por esse personagem. Por último, o leitor não deve interpretar os fatos narrados como uma leitura alegórica ou poética. Seria preciso que o evento fantástico não fosse explicado até o final da narrativa, caso contrário, o texto poderia pertencer a outros gêneros, como o maravilhoso ou o estranho. Para Todorov (2014, p. 48), pode-se definir como estranho o acontecimento que parece sobrenatural, mas que, no final, é explicado racionalmente, que não altera as leis da natureza. Por sua vez, o maravilhoso pode ser definido como o acontecimento que recebe novas leis da natureza e termina com uma aceitação natural do sobrenatural. Já no fantástico, a dúvida entre o real e o imaginário deve permanecer após o término da narrativa.

Por sua vez, o que caracteriza o modo fantástico, para Remo Ceserani (2006, p. 68), são os "procedimentos formais e sistemas temáticos que (embora não sendo exclusivos dele) são muito frequentes no mundo fantástico e foram menos ou mais amplamente aplicados, diversamente combinados". De acordo com Filipe Furtado (2009), o fantástico como modo abarcaria as narrativas que apresentariam o sobrenatural. No entanto, o teórico português ressalta que o sobrenatural não seria o termo mais apropriado, pois tal concepção varia conforme as épocas e as culturas. Furtado (2009) prefere adotar o termo "metaempírico" como balizador do fantástico, por abarcar "não só as manifestações de há muito denominadas sobrenaturais, mas, ainda, outras que, não o sendo, também podem parecer insólitas e, eventualmente, assustadoras [...]". Por sua vez, Flavio García (2019) defende que essa definição de Furtado se aproxima do conceito de insólito, proposto por autores como Lenira Marques Covizzi (1978). Portanto, neste artigo, entendemos o fantástico como um sinônimo de insólito, um termo que vem sendo utilizado por diversos pesquisadores, por ampliar os horizontes de leitura da narrativa fantástica.

Covizzi é apontada por muitos estudiosos como uma das pioneiras do estudo sobre o insólito no Brasil. Na década de 1970, ela se propõe a analisar a obra de João Guimarães Rosa e a de Jorge Luis Borges, a partir do conceito de insólito que, segundo ela, teria um sentido de "não-acreditável, incrível, desusado" (COVIZZI, 1978, p. 36). O insólito, para Covizzi (1978, p. 26, grifos da autora), é sinônimo de um evento sem explicação, que carrega um "sentimento de inverossímil, incômodo, infame, incongruente, impossível, infinito, 
incorrigível, incrível, inaudito, inusitado, informal...”. A partir de sua conceituação, Covizzi (1978, p. 36, grifos da autora) destaca algumas manifestações congêneres ao insólito, como o fantástico, o maravilhoso, o absurdo, o misterioso etc. Portanto, o termo "insólito" será utilizado para englobar as diferentes manifestações que têm em comum um evento inusual.

A narrativa-moldura de Pinheiro Chagas dialoga com outras obras literárias, sobretudo com Decamerão (1348-1353), de Giovanni Boccaccio. André Jolles (1976, p. 188-189) defende que a produção de Boccaccio seria exemplar de uma narrativa curta, surgida na Toscana, denominada "novela", que poderia ser produzida em coletânea ou isolada:

[...] as coletâneas de novelas têm, em geral, uma forma herdada do Decameron, sua grande precursora. As narrativas estão todas ligadas entre si por um quadro que assinala, entre outras coisas, onde, em que ocasião e por quem essas novelas são contadas.

Jolles (1976) menciona outros exemplares que empregam a narrativa-moldura, como a coletânea Le piacevoli notti (As noites agradáveis) (1550), de Giovanni Francesco Straparola, e Lo cunto de li cunti (O conto dos contos) (1634-1636), de Giambattista Basile. Todavia, de acordo com o investigador, existiriam diferenças entre essas obras, pois Decamerão seria uma novela toscana, que procuraria "contar um fato ou um incidente impressionante de maneira tal que se tenha a impressão dum acontecimento efetivo" (JOLLES, 1976, p. 189). Por sua vez, as produções de Straparola e de Basile, apesar de utilizarem a narrativa-moldura, não poderiam ser consideradas novelas toscanas, pois elas são "narrativas do tipo que conhecemos através dos contos de Grimm, narrativas que de maneira nenhuma nos dão a impressão de um acontecimento efetivo" (JOLLES, 1976, p. 189).

Em A lenda da meia-noite, de Pinheiro Chagas, tem-se uma narrativa-moldura em que surge não somente o maravilhoso, mas também outros modos literários agrupados na categoria do insólito ficcional. Pinheiro Chagas tem Decamerão como modelo para a sua coletânea e, ao mesmo tempo, dialoga com obras do insólito, pois a estrutura de moldura também é empregada em produções góticas, maravilhosas e fantásticas.

Consideramos a metaficção como uma narrativa fundada na metalinguagem (cf. AVELAR, 2010). Em A lenda da meia-noite, a metaficção se dá pelo fato de o fantástico ser o modo literário empregado por Pinheiro Chagas e, ao 
mesmo tempo, tema de discussão dos personagens ao longo da narrativa-moldura. Linda Hutcheon (1985, p. 92) comenta que a "metaficção caracteriza-se, decididamente, por uma utilização irónica [...] de formas paródicas”. Verifica-se que Pinheiro Chagas faz uso do insólito, mas também parodia as narrativas fantásticas. Ademais, de acordo com Hutcheon (1985, p. 17), “a paródia é, pois, uma forma de imitação caracterizada por uma inversão irónica [...]. [Uma] repetição com distância crítica, que marca a diferença em vez da semelhança”. Em A lenda da meia-noite, a paródia se dá na narrativa-moldura, a partir da discussão sobre o conceito de fantástico, na qual são evidenciados os exageros dos elementos típicos das narrativas insólitas, e nos comentários feitos sobre os contos narrados.

É preciso considerar que a narrativa-moldura é um procedimento utilizado em outras produções de Pinheiro Chagas. Em estudo sobre os romances históricos desse escritor, Jane Adriane Gandra (2012, p. 173) discorre que uma característica de A história alegre de Portugal (1880) "é a maneira como se dá a narração da História nacional, que é muito aproximada ao entrecho de Decamerão". Nessa obra, tem-se um professor aposentado que narra, em dez noites, episódios históricos de Portugal. Além disso, Gandra (2012, p. 174) destaca que a estrutura do livro florentino também é recuperada em A lenda da meia-noite, para compor narrativas que "foram feitas seguindo-se a linha da literatura gótica ou de terror”. Podem-se ampliar as considerações feitas por Gandra (2012) porque, nesse volume, além do gótico e do terror, há também o fantástico, o maravilhoso e a lenda. Por sua vez, Helena Carvalhão Buescu (1997, p. 88 ) afirma que a composição e a estrutura das obras de Pinheiro Chagas são heterogêneas e explica que A lenda da meia-noite

[...] segue o exemplo clássico de uma "sociedade" em torno da qual se forma o tecido narrativo, cada um dos interlocutores comprometendo-se a, cada noite, contar uma história fantástica. De novo a estrutura da obra é heterogénea e curiosa, jogando na multiplicidade dos níveis, entrechos e narradores (um deles é... uma bolsa verde!) e na forma como as narrativas encaixadas contribuem para a evolução da acção principal.

Visível em mais de uma obra de Pinheiro Chagas, a estrutura em forma de moldura é um procedimento valorizado por esses estudiosos e exclusiva da coletânea A lenda da meia-noite, isto é, ela só aparece quando tais narrativas são publicadas conjuntamente. 
A narrativa-moldura de A lenda da meia-noite tem como espaço uma casa antiga situada numa área rural de uma vila, na província de Beira-Baixa, próxima à Serra da Estrela, região conhecida por ser uma das mais frias de Portugal. A grandiosidade da residência e o barulho da chuva e do vento evidenciam os traços do gótico e do terror: "nos amplos salões desses edifícios isolados ouvem-se rumores sinistros, e sons misteriosos, e o vento, fazendo ranger os pilares da varanda, entoa a música triste das lendas populares" (CHAGAS, 1874, p. 4). Os moradores da casa, os Viscondes da Fragoza, recebem convidados para uma temporada de caça, mas, por causa dos dias chuvosos e frios, essa atividade é interrompida. Devido à adversidade climática e percebendo que parte do grupo sente medo da tempestade e dos traços insólitos do edifício, o doutor Macedo, um dos integrantes, sugere uma contação de histórias:

0 mau tempo ameaça prolongar-se, e nós ou não podemos caçar, ou não podemos prolongar a caça por todo o dia, sob pena de estoirarmos aí de frio por essa serra. Portanto à noite estamos frescos e descansados, e podemos protrair o serão. Proponho que organizemos um Decamerone para zombarmos da meia-noite, como os narradores de Boccaccio zombaram da peste em Florença. Cada um de nós, que se sentir para isso com forças, se compromete a compor uma história fantástica, uma lenda, um conto maravilhoso que será lido aqui ao bater da meia-noite (CHAGAS, 1874, p. 14).

De acordo com esse personagem, a contação de histórias amenizaria o temor da noite e seria uma forma alternativa de entretenimento. O esquema proposto pelo convidado remete à estrutura do Decamerão, obra que contextualiza o período de peste bubônica, que assolou a Itália entre 1348 e 1398 e que é composta por cem narrativas contadas, durante dez dias, por dez personagens que fogem de Florença. Embora não seja objetivo uma comparação minuciosa entre as duas produções, há algumas similaridades entre elas: as narrativas contadas servem como entretenimento e os personagens se encontram no campo, devido a uma adversidade. Todavia, a principal analogia entre as duas produções é a utilização da moldura.

De acordo com Dóris Nátia Cavallari (2006), por meio desse procedimento, a obra de Boccaccio apresenta uma coerência temática que garantiria uma organicidade, fazendo do texto "um conjunto de narrativas coligidas a um fim, o de organizar o caos pela narrativa”. Assim como no Decamerão, há uma coerência temática nas narrativas de A lenda da meia-noite. No texto de 
Boccaccio, a temática é definida conforme o dia (jornada); já na obra de Pinheiro Chagas, reúnem-se histórias fantásticas, lendas e contos maravilhosos (expressões utilizadas pelos próprios personagens), ou seja, textos que estariam no âmbito do insólito.

Cavallari (2006) também destaca que "os amigos unem-se e rompem com a impotência causada pela solidão e pelo medo. O agrupamento possibilita o resgate da civilidade". Dessa forma, a contação de histórias no Decamerão manteria viva a civilidade entre o grupo, da mesma forma como ocorre em $A$ lenda da meia-noite. O pedido de casamento entre dois jovens, conhecidos desde a infância, evidencia que a reunião colabora para a socialização e para o entretenimento.

Observa-se ainda que, na citação transcrita anteriormente da obra portuguesa, as histórias contadas teriam como objetivo amenizar o medo da meia-noite, hora considerada soturna por alguns convidados. A utilização da expressão "zombar da meia-noite" pode indicar que haveria, nesses relatos, a inversão de sentidos, isto é, o medo daria lugar para o riso, provocando a paródia. Todavia, ainda que alguns desses textos não tenham todos os atributos esperados de um conto fantástico para alguns dos ouvintes, é na moldura que se encontram a metaficção e considerações irônicas sobre o teor fantástico das histórias contadas.

Entre os convidados dos Viscondes da Fragoza, destacam-se seus filhos Leonor, uma jovem, e as crianças Álvaro e Julia; o doutor Macedo, médico que está na serra, para cuidar da própria saúde; Lucio Valença, escritor de "certa aura"; o Comendador Madureira e sua jovem filha Isaura; Henrique Osório, moço da região de Fundão; e Roberto Soares, jornalista e antigo escritor. A personagem Isaura, moça pálida, sente medo das trovoadas, e a sua afirmação - de que o clima tempestuoso lembraria uma noite de lenda alemã - inicia uma discussão sobre o fantástico, pois, para o doutor Macedo, o vento não seria o único atributo das lendas germânicas, faltariam ainda "a chuva, a trovoada, a neve e muitos outros acessórios" (CHAGAS, 1874, p. 7). Evidencia-se o aspecto obscuro da noite, dialogando com as acepções defendidas por Ceserani (2006), que destaca que a noite, a escuridão, o mundo obscuro e as almas do outro mundo formam um sistema recorrente na literatura fantástica.

Segundo Ceserani (2006, p. 77), “a ambientação preferida pelo fantástico é aquela que remete ao mundo noturno". O pesquisador italiano ainda destaca o título Peças noturnas (1817), do alemão E. T. A. Hoffmann, um dos pioneiros 
da literatura fantástica europeia. Por utilizar a noite como plano de fundo para suas composições, a obra desse autor poderia representar um modelo para os convidados dos Viscondes da Fragoza, pois, em diversos momentos, o nome de Hoffmann é citado. Para esses integrantes, o verdadeiro conto fantástico é aquele que traz uma ambientação noturna, com elementos que acentuem o aspecto obscuro da noite.

Além disso, de acordo com esses personagens, o efeito fantástico somente seria atingido se o texto fosse lido sob determinadas circunstâncias. Isaura afirma gostar das lendas sobrenaturais, mas "gosto de as ler em Lisboa, no meu gabinete e à luz do sol” (CHAGAS, 1874, p. 7). Por seu turno, o doutor Macedo lembra que essa atitude remeteria à mise-en-scène, termo empregado no teatro. O personagem Lucio comenta que

[...] o doutor entende que as lendas devem ser lidas e apreciadas à noite, no meio do silêncio geral, quando se está sozinho, num velho castelo de Anna Radcliffe, cheio de alçapões e de subterrâneos, quando o vento geme lugubremente nos corredores, e faz oscilar a luz da vela que alumia a nossa solitária vigília. Creio que o doutor, acudiu Lucio voltando-se rindo para ele, dispensa que a vela esteja num crânio, em vez de estar num castiçal, e que haja um cemitério por baixo da janela.

- Dispenso... dispenso... acudiu o doutor com a mesma imperturbável gravidade, quero dizer... não julgo indispensáveis esses acessórios, mas não posso negar que aumentavam de um modo notabilíssimo o efeito fantástico da narrativa legendária (CHAGAS, 1874, p. 7).

A mise-en-scène remete a um procedimento formal típico da literatura fantástica. Como destaca Ceserani (2006, p. 75),

[...] é difundida no fantástico a tendência a utilizar, no âmbito narrativo, procedimentos sugeridos pela técnica e pela prática teatral; isso ocorre evidentemente por um gosto pelo espetáculo [...] e por uma necessidade de criar no leitor um efeito de "ilusão".

Para esses personagens, o fantástico seria atingido por meio de uma série de elementos que criaria um efeito de ilusão, principalmente, pela constituição do cenário. Em primeiro lugar, as narrativas insólitas deveriam ser apreciadas à noite, na quietude. Em segundo lugar, ao citar a inglesa Ann Radcliffe, percebe-se que o cenário típico de seus romances góticos contribuiria para a irrup- 
ção do insólito. Na citação extraída da obra de Chagas (1874) indicada anteriormente, há uma crítica metaficcional aos excessos de elementos típicos da literatura gótica e de terror, pois Lucio se refere, em tom jocoso, às velas dentro de crânios e aos cemitérios.

Para o doutor Macedo, as narrativas do insólito seriam como os abacaxis: "Há os nascidos ao ar livre, na sua terra própria, e há os desabrochados artificialmente com o calor da estufa" (CHAGAS, 1874, p. 8). Isto é, o fantástico estaria propenso a surgir em circunstâncias soturnas, como numa casa antiga ou numa noite de inverno com raios e trovões. Contudo, uma narrativa insólita perderia seu efeito se ela se passasse "numa sala de Lisboa, forrada de espelhos, ornada de macios sofás, entre os rumores meridianos da rua, à luz clara e alegre do sol" (CHAGAS, 1874, p. 8). Portanto, para os personagens, o fantástico somente se manifestaria em narrativas cujos cenários fossem sombrios.

No entanto, essa consideração é bastante questionável, pois o insólito não depende exclusivamente de seu espaço narrativo. Por exemplo, Ceserani (2006, p. 111) demonstra que, ao longo da produção do francês Theóphile Gautier, o fantástico nórdico, noturno e perturbador "sutilmente vai mudando para um fantástico mediterrâneo - ou até oriental - luminoso e sublimado". Ademais, o doutor Macedo cita um artefato bastante usual nas narrativas insólitas: o espelho, que, muitas vezes, está relacionado ao tema do duplo, como aponta Ceserani (2006, p. 83). Percebe-se, portanto, o equívoco do personagem ao destacar o cenário como único indício para o fantástico, pois ele pode se manifestar em espaços ensolarados e em salas com muitos espelhos.

A partir do temor sentido por Isaura, após o sino de uma igreja distante anunciar a meia-noite, há o ensejo para a contação de histórias. A jovem considera que a "meia-noite é a hora dos fantasmas, é a hora das aparições!" (CHAGAS, 1874, p. 12). No entanto, para o doutor Macedo, a meia-noite somente assustaria pessoas sensíveis, que pensariam que algo poderia acontecer nesse horário. Por acreditar que o grupo seria "capaz de afrontar dois subterrâneos de Ann Radcliffe, três conventos de Lewis, reforçados ainda pelos mil e um fantasmas de Alexandre Dumas" (CHAGAS, 1874, p. 12), ele propõe que, nos próximos dias, os convidados contem histórias para afastar o medo da meia-noite, temor percebido por ele com certo desdém.

Portanto, as histórias contadas nos dias seguintes deveriam atenuar o medo das narrativas sombrias, como as de Radcliffe. São mencionados ainda Lewis, autor de O monge (1796), e Dumas, autor de Os mil e um fantasmas 
(1849), obra que dialoga com As mil e uma noites, por trazer, como na coletânea oriental, contos insólitos numa narrativa-moldura. A produção de Dumas pode ter servido de modelo para a coletânea de Pinheiro Chagas, pois, na obra francesa, um grupo de conhecidos se reúne para caçar e, durante o jantar, são contadas histórias insólitas.

O primeiro conto de A lenda da meia-noite é narrado por Henrique Osório e intitula-se "Julieta". Nele, tem-se uma história dentro da outra. Próximo à meia-noite, um grupo de amigos discute sobre a existência de fantasmas. Roberto, um dos integrantes, relata uma experiência insólita que acontecera com ele: após assistir a uma ópera em Lisboa, ele segue uma moça que vira num camarote. Ao chegar a uma travessa, a jovem, chamada Julieta, pede para que Roberto encontre com ela, naquele lugar, no dia seguinte, à meia-noite. Depois de alguns encontros, o moço é convidado a entrar na casa dela, mas, após atravessar uma porta que dá para um jardim, ele se depara com um cemitério. Julieta arrasta Roberto para um sepulcro, ele desmaia e acorda no dia seguinte, em casa.

Após o término de "Julieta", os ouvintes aplaudem, menos Isaura, que boceja. Por essa razão, Henrique considera que a contação de histórias, "se não cura dos terrores, que sentem as pessoas nervosas, ao menos concilia-se o sono que afugenta os fantasmas" (CHAGAS, 1874, p. 44). Para Isaura, a falta de interesse pela narrativa se justifica pelo fato de o narrador não ter tratado bem as mulheres pálidas, pois, nesse conto, elas seriam representações sobrenaturais. Por sua vez, Leonor faz uma crítica à narrativa:

0 teu romance é uma loucura. Estás engraçado com as tuas idealizações constantes. Queres mulheres sobrenaturais, entes fantásticos. [...] Se achas que é lisonjeiro para uma mulher perder sua realidade para agradar ao homem que diz amá-la, morrer primeiro para ser depois desposada por ele em forma espectral, como no Noivado do sepulcro de Soares de Passos... (CHAGAS, 1874, p. 45).

O poema "O noivado do sepulcro" (1856) traz um casal separado pela morte: o homem morto vaga pelo cemitério à espera da amada. No entanto, Leonor ironiza o conto lido, por, assim como no poema de Soares de Passos, idealizar as mulheres como seres sobrenaturais e por evidenciar os excessos do amor. A partir dos comentários feitos pelos convidados, fica subentendido que a história narrada por Henrique teria como objetivo impressionar Isaura, uma jovem pálida. 
Roberto Soares narra a segunda história, “A visão do precipício”, que fora transmitida por um conhecido e, assim como a anterior, é um conto dentro de outro. Trabalhadores rurais, assustados com uma forte tempestade, fazem comentários sobre a lenda do Fantasma do Açude. Um deles conta que, numa época indefinida da Idade Média, Raymundo, filho de um importante fidalgo da região, enamora-se por Branca e, antes de partir para as cruzadas, jura amor eterno à jovem. No entanto, durante a batalha, o cavaleiro apaixona-se, como se por efeito de magia, por Zoraida, uma moura. A notícia chega a Branca, e ela se suicida, atirando-se de um precipício, perto de um rio. Tempos depois, Raymundo e Zoraida passam por esse local e zombam de um cruzeiro construído lá. Então, a moura se transforma numa figura demoníaca e se atira, com Raymundo, para o penhasco. O trabalhador explica que corre a lenda de que, em noites de tempestades, são vistos nesse local os fantasmas de Branca e Raymundo.

Percebe-se que a leitura desse conto teve pouco efeito para os ouvintes. O escritor Lucio ironiza a narrativa, por ela se passar na Idade Média: “Estava já prevendo que íamos descambar em plena Idade Média. O nosso amigo [...] não pode dispensar-se de consagrar um vivo afeto às couraças da sua adolescência, e as achas de armas da sua criação. Fez-nos voltar para 1830" (CHAGAS, 1874 , p. 80). Para ele, o procedimento de recuo no tempo seria típico do primeiro romantismo português e estaria ultrapassado. Roberto Soares, antigo escritor romântico, admite que o seu conto teria alguns elementos dos escritos da época mencionada por Lucio e elogia as narrativas que abusavam "do veneno e do punhal e dos solares e das chácaras e dos cavaleiros que voltavam da cruzada" (CHAGAS, 1874, p. 80). Por sua vez, Henrique afirma o seguinte:

Eu mesmo vi-me em ânsias para resistir ao sono. Quem atura hoje um destes solaos cansados e gastos que deliciaram a velha geração, com seus cavaleiros de armas negras, e os seus diabos disfarçados em mulheres formosas, e os seus fidalgos que venderam a alma a Satanás como na Dama pé de cabra de Alexandre Herculano, ou na Torre de Caim de Rebelo da Silva? Isso foi bom no seu tempo, hoje está longe do maravilhoso moderno [...] (CHAGAS, 1874, p. 81).

O comentário converge das considerações feitas por Lucio, pois ambos concordam que a temática de "A visão do precipício" estaria ultrapassada. Segundo Henrique, o público leitor estaria cansado de narrativas protagonizadas por cavaleiros, ambientadas na Idade Média e de alguns procedimentos, como a personagem feminina estar associada ao diabólico, como ocorre em "A 
dama pé-de-cabra" (1843), de Alexandre Herculano, e em "A torre de Caim" (1846), de Rebelo da Silva, contos fantásticos do romantismo português.

$\mathrm{Na}$ noite seguinte, o doutor Macedo narra "A igreja profanada”. Trata-se de um barqueiro e de um passageiro que estão no mar e ouvem o sino de uma igreja anunciar a meia-noite. Eles ouvem melodias musicais vindas da água e veem um clarão vermelho. O passageiro conta a lenda de Guilherme e Inês, dois irmãos que viveram um amor incestuoso. É relatado que, numa noite de tempestade, os jovens foram se abrigar numa igreja e lá se depararam com uma celebração religiosa. O sacerdote tenta excomungar os irmãos, mas ele acaba sendo morto por Guilherme. O passageiro afirma que, toda meia-noite, "acendem-se os círios na igreja sepultada, e, no fundo do mar, os réprobos entoam os salmos da penitência" (CHAGAS, 1874, p. 109).

Após o término da narrativa, há uma nota de rodapé explicando que o conto teria sido inspirado num pequeno relato do suposto livro História e tratado das ciências ocultas, do conde de Résie. Ainda há um lamento por escritores, como Herculano, não terem tido o conhecimento dessa obra. Se, anteriormente, uma das narrativas de Herculano fora citada como um modelo ultrapassado, agora o autor é elogiado por ter dado, em “A dama pé-de-cabra”, um tratamento artístico a uma antiga lenda. Ao contrário da narrativa anterior, “A igreja profanada" é bem recebida pelos convidados. Henrique, por exemplo, afirma que sentiu medo durante a leitura, e, só então, o doutor Macedo revela que a história teria sido escrita por Leonor, para impressionar Henrique, pois ela estaria interessada nele.

Por ser um texto longo, o escritor Lucio Valença narra as "Memórias de uma bolsa verde", às dez e meia da noite, no quarto dia. Ele explica que essa narrativa é fantástica por apresentar como "personagem principal [...] um ente inanimado, [e que] tinha contudo uma pequena parte propriamente legendária" (CHAGAS, 1874, p. 116). Como o próprio título sugere, o elemento insólito é uma bolsa verde que narra, para um escritor, a sua vida, desde a sua fabricação até os seus últimos dias.

Após a leitura do conto, parte dos ouvintes está dormindo. O doutor Macedo reclama que Lucio saíra do programa, por ter lido "um romance humorístico debaixo da bandeira de conto da meia-noite" (CHAGAS, 1874, p. 202). Para ele, a narrativa não seria fantástica: "Então isto é um conto fantástico? Você nunca leu Hoffmann? Você nunca leu Carlos Dickens? [...] Então onde há aqui espectro? Onde há visão? Onde há os terrores legendários da meia-noite?" (CHAGAS, 1874, p. 202). 
Esse comentário reforça as expectativas de leitura que os convidados têm de um conto fantástico. Primeiramente, percebe-se que o modelo esperado seria o produzido por autores como Hoffmann e Dickens. Ademais, para os personagens, o texto insólito deve privilegiar o noturno e a meia-noite, e, de preferência, se passar numa noite de tempestade, ter como cenário um castelo ou uma casa antiga e apresentar seres sobrenaturais, como fantasmas. As histórias contadas até então satisfazem essas expectativas de leitura, mesmo que algumas delas sejam criticadas. O narrador de "A visão do precipício", por exemplo, destaca esses elementos logo no início da narração: "Estou obrigado moralmente a apresentar alçapões, subterrâneos, e donzelas perseguidas. Se não invento por aí uns quatro assassínios, estou perdido no conceito de certos leitores!" (CHAGAS, 1874, p. 49). Por sua vez, “As memórias de uma bolsa verde" é um apólogo, isto é, uma narrativa protagonizada por um objeto, e somente esse atributo não seria o suficiente para que esse conto fosse considerado fantástico, de acordo com os ouvintes.

Por fim, Isaura propõe que, na noite seguinte, um conto seja lido para Álvaro e Julia, filhos pequenos dos Viscondes da Fragoza. Ao contrário das anteriores, essa narrativa não é contada à meia-noite, mas ao anoitecer. Trata-se de um conto maravilhoso intitulado "Dominus tecum". ${ }^{3}$ Patrício, um camponês, pede um favor para um duende, prometendo recompensá-lo, mas, após o trato, não cumpre o combinado. $O$ duende então condena o camponês a servi-lo por sete anos e um dia. Numa manhã, o duende, prestes a completar mil anos, decide se casar com Jenny, uma jovem que se casaria com outro rapaz naquela noite. Quando chegam à cerimônia, eles veem que a noiva espirra, e o duende comenta: "se ela dá mais dois espirros e ninguém lhe diz Dominus tecum, é minha; foi isso o que Satanás me prometeu" (CHAGAS, 1874, p. 222). Sabendo dos planos malignos do duende, após o terceiro espirro, Patrício saúda a jovem. O duende, irritado, liberta Patrício, e os noivos agradecem ao camponês.

No dia seguinte à leitura de "Dominus tecum”, a mãe de Henrique Osório vai até a casa dos Viscondes de Fragoza para pedir ao filho a mão de Leonor. A narrativa-moldura, portanto, tem um desfecho típico das obras sentimentais: o casamento, tal como afirma o doutor Macedo: "das nossas lendas da meia-

3 José Leite de Vasconcelos (1882, p. 254) explica que o ato de saudar alguém que espirra é motivado pela crença de que os espíritos entrariam no corpo das pessoas, sobretudo para produzir doenças. Conforme postula esse etnógrafo português, "quando alguém espirra, os circunstantes descobrem-se e dizem: “Jesus! Dómis teco! (Dominus tecum), Viva!" (VASCONCELOS, 1882, p. 253, grifos do autor). 
-noite saiu este casamento [...] tem a lenda da meia-noite uma conclusão inesperada: mas isso foi bom para que tivesse alguma" (CHAGAS, 1874, p. 225-226, grifo do autor). Além disso, reforça-se a importância da contação de histórias como um entretenimento: "E ainda que outra coisa não se alcançasse, logrou-se passarem-se algumas noites agradavelmente" (CHAGAS, 1874, p. 227).

A moldura de A lenda da meia-noite, por meio da metaficção, trata sobre o fantástico, conceito empregado pelos próprios personagens. O espaço soturno da casa dos Viscondes de Fragoza e da noite tempestuosa outonal serve de motivação para a contação de histórias, e, a partir disso, tem-se uma discussão sobre os elementos típicos das narrativas insólitas, em que são privilegiados os textos que preencham as expectativas de leitura desses personagens, mas os contos que trazem esses atributos também são ironizados, como "Julieta" e "A visão do precipício". Além disso, a moldura de Pinheiro Chagas também é uma narrativa sentimental, e, embora o doutor Macedo afirme que o casamento não seria o desfecho mais esperado, precisamos considerar que, ao longo do texto, são destacados os interesses sentimentais de Henrique por Isaura e por Leonor, preferida por não ser uma mulher frívola como a jovem pálida, ou seja, o casamento é previsível.

Pinheiro Chagas, nessa coletânea, dá diversos tratamentos ao insólito. Em "Julieta", o personagem Roberto acredita que a visão do fantasma da jovem não foi uma alucinação, pois ele se recorda atentamente dos detalhes. No entanto, ele também afirma ter uma imaginação desregrada. Por apresentar uma hesitação, o conto aproxima-se do fantástico todoroviano, pois pode-se questionar se os episódios teriam sido sonho, imaginação, ou se, de fato, teriam ocorrido. Em "A visão do precipício" e "A igreja profanada”, as personagens femininas estão associadas ao diabólico, e há um aspecto lendário por tratarem de eventos que supostamente teriam acontecidos há muito tempo, durante a Idade Média, numa linha tênue entre o maravilhoso e o fantástico. Por sua vez, o maravilhoso também aparece em "Dominus tecum" e em "As memórias de uma bolsa verde", por ser um apólogo protagonizado por uma bolsa.

\section{CONSIDERAÇÕES FINAIS}

Parte dos contos de A lenda da meia-noite foi publicada em, pelo menos, dois momentos: o primeiro, na década de 1860, em periódicos, e o segundo, na 
década seguinte, em livro. A principal diferença é que esses textos, quando compilados, estão unidos por uma narrativa-moldura. Portanto, a partir da leitura dessa obra, conclui-se que, se os contos forem lidos separadamente, eles não perdem significação, mas esse procedimento garante uma coerência temática sustentada principalmente pela metaficção, que dá novas possibilidades de leitura.

$\mathrm{Na}$ narrativa-moldura, o fantástico é utilizado como um dos temas principais, servindo de ensejo para a reunião dos cinco contos. A partir das discussões travadas entre os personagens, fica evidente que, para eles, a noite seria o elemento fundamental da narrativa fantástica, que deve apresentar ainda, entre outros elementos, uma casa antiga ou um castelo, uma tempestade, um espectro, uma visão sobrenatural etc. Os três primeiros contos reunidos seguem grande parte desse modelo, mas, apesar de serem elogiados, também são criticados. Todavia, “As memórias de uma bolsa verde", por ser um apólogo e por não ter as características mencionadas, é desprezado pelos ouvintes, e "Dominus tecum", um conto maravilhoso destinado às crianças, é deixado de lado por parte dos convidados.

Com a metaficção, tem-se uma discussão sobre o conceito de fantástico e uma crítica metaliterária e paródica às narrativas insólitas, isto é, os contos reunidos na coletânea são alvos de comentários feitos pelos personagens da narrativa-moldura. Dessa forma, Pinheiro Chagas, num jogo bastante interessante, reaproveita seus contos que outrora já tinham sido publicados e insere-os num novo contexto; agora, transformadas por meio da metaficção, essas narrativas passam a ser supostas produções de seus personagens.

Pinheiro Chagas, apesar de não ser reconhecido como um autor vinculado ao insólito, publica seus textos, entre as décadas de 1860 e 1870, em Portugal, no mesmo período em que também são publicadas diversas produções insólitas, como os Contos fantásticos (1865), de Teófilo Braga, as narrativas da Gazeta de Portugal (1866 e 1867), de Eça de Queirós, compiladas no volume Prosas bárbaras (1903), e os Contos (1868), de Álvaro do Carvalhal.

A coletânea A lenda da meia-noite merece destaque, por ser uma obra que apresenta uma moldura, um procedimento que mantém uma coerência temática, cujo assunto principal é o fantástico. A moldura, embora não seja indispensável à obra, garante originalidade, por não ser recorrente em outras produções portuguesas fantásticas da época e por dar um tratamento metaficcional ao fantástico. 


\section{The unusual in the frame narrative of $A$ lenda da meia-noite, by Pinheiro Chagas}

\section{Abstract}

We aim to highlight Manuel Pinheiro Chagas' contribution to the Portuguese literature of the unusual through the analysis of the frame narrative of the collection A lenda da meia-noite (1874), which brings five unusual short stories.

\section{Keywords}

Unusual. Frame narrative. A lenda da meia-noite.

\section{REFERÊNCIAS}

AVELAR, M. Metaficção. In: CEIA, C. (coord.). E-dicionário de termos literários. 2010. Disponível em: https://edtl.fcsh.unl.pt/encyclopedia/metaficcao/. Acesso em: 16 dez. 2020.

BATALHA, M. C. Introdução. In: BATALHA, M. C. (org.). O fantástico brasileiro: contos esquecidos. Rio de Janeiro: Caetés, 2011. p. 9-19.

BATALHA, M. C. Literatura fantástica: algumas considerações teóricas. Revista Letras \& Letras, Uberlândia, v. 28, n. 2, p. 481-504, jul./dez. 2012.

BUESCU, H. C. Chagas, (Manuel Joaquim) Pinheiro. In: BUESCU, H. C. (coord.). Dicionário do romantismo literário português. Lisboa: Editorial Caminho, 1997. p. 88-89.

CALVINO, I. Introdução. In: CALVINO, I. (org.). Contos fantásticos do século XIX: o fantástico visionário e o fantástico cotidiano. São Paulo: Companhia das Letras, 2004. p. 9-18.

CAVALLARI, D. N. O Decameron de G. Boccaccio: alguns traços de intertextualidade. Revista Recorte, v. 3, n. 2, 2006. Disponível em: http://periodicos.unincor.br/index.

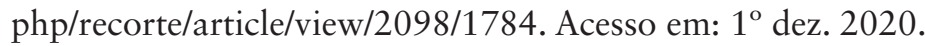

CESERANI, R. O fantástico. Curitiba: Editora UFPR, 2006.

CHAGAS, M. P. A lenda da meia-noite. Porto: Livraria Moré, 1874.

COVIZZI, L. M. O insólito em Guimarães Rosa e Borges. São Paulo: Ática, 1978.

FURTADO, F. Fantástico (modo). In: CEIA, C. (coord.). E-dicionário de termos literários. 2009. Disponível em: https://edtl.fcsh.unl.pt/encyclopedia/fantastico-modo/. Acesso em: 14 dez. 2020. 
GANDRA, J. A. Pinheiro Chagas, um escritor olvidado. 2012. Tese (Doutorado em Estudos Comparados de Literaturas de Língua Portuguesa) - Universidade de São Paulo, São Paulo, 2012.

GARCÍA, F. Insólito ficcional. In: REIS, C. et al. (ed.). Dicionário digital do insólito ficcional (e-DDIF). Rio de Janeiro: Dialogarts. 2019. Disponível em: http://www.insolitoficcional.uerj.br/i/insolito-ficcional/. Acesso em: 14 dez. 2020.

GOÉS, L. P. Lenda. In: CEIA, C. (coord.). E-dicionário de termos literários. 2009. Disponível em: https://edtl.fcsh.unl.pt/encyclopedia/lenda/. Acesso em: 16 dez. 2020.

HUTCHEON, L. Uma teoria da paródia - ensinamentos das formas de arte do século XX. Lisboa: Edições 70, 1985.

JOLLES, A. O conto. In: JOLLES, A. Formas simples: legenda, saga, mito, adivinha, ditado, caso, memorável, conto, chiste. São Paulo: Cultrix, 1976. p. 181-204.

TODOROV, T. Introdução à literatura fantástica. 4. ed. São Paulo: Perspectiva, 2014.

VASCONCELOS, J. L. de. Tradições populares de Portugal. Porto: Livraria Portuense de Clavel \& C. ${ }^{a}$ - Editores, 1882.

VELOSO, J. A. G. A (de)formação da imagem: Pinheiro Chagas refletido pelo monóculo de Eça de Queirós. 2007. Dissertação (Mestrado em Letras - Estudos Comparados de Literaturas de Língua Portuguesa) - Universidade de São Paulo, São Paulo, 2007. 